\title{
J3:
}

Journal of Business Models

\section{Competing With the Use of Business Model innovation - an Exploratory Case Study of the Journey of Born Global Firms.}

Marlene Johansson' \& Jan Tony Abrahamsson²

\begin{abstract}
Purpose: The purpose of this article is to investigate how business models are used by born global firms to act upon new business opportunities and how they manage business model innovation over time to prosper and grow.
\end{abstract}

Design/Methodology: The study is based on three exploratory case studies of born global firms in mobile communication, financial services and digital music distribution.

Findings: Three interrelated capabilities to manage business model innovation are articulated in the context of born global firms; sensing capabilities, entrepreneurial capabilities and relational capabilities and four propositions are formulated. We find that business model innovations are used as a tool by maturing born global firms to navigate the value chains and achieve international growth. We further propose that born global need the capabilities to balance different business model designs simultaneously and to manage its business model innovation in a timely manner.

Originality: This article contributes to both the business model literature and research of international entrepreneurship. By putting business model research into the dynamic context of rapidly internationalizing born global firms, we contribute to the field of business model research with findings of how business models are used in the internationalization processes. Certain capabilities are needed to manage business model innovation for born global firms to dynamically use business models as a tool in the international growth overtime.

Keywords: Internationalization, born global firms, business model innovation, dynamic capabilities

1 Marlene Johansson, Department of Business Administration, Centre for Inter-organizational Innovation Research, Umeå School of Business and Economics, Umeå University, Sweden, marlene.johansson@usbe.umu.se

2 Jan Abrahamsson, Department of Business Administration, Centre for Inter-organizational Innovation Research, Umeå School of Business and Economics, Umeå University, Sweden, jan.abrahamsson@usbe.umu.se 


\section{Introduction}

During the last few decades, drivers such as open innovation systems, rapid development of new technologies and the globalization of markets have changed the competitive game (Chesbrough, 2006; Casadesus-Masanell and Ricart, 2010). These changes have re-arranged previously closed value chains and competitive structures and opened up for new business opportunities (Bengtsson and Johansson, 2012). A type of firms that have capitalized on these emerging business opportunities are born global firms; young firms characterized by a rapid international growth and innovativeness from their inception (Oviatt and McDougall, 1994; Moen and Servais, 2002; Gabrielsson, et al. 2008). Born global firms can identify and act upon novel opportunities due to fast access to international networks, (Coviello, 2006) international customers (Gabrielsson, et al., 2008) and international financing (Makela and Makula, 2005). However, with new business opportunities also comes remarkable challenges in regards to how to design the business model to present and package its value proposition to customers, and to create, deliver and capture value in a marketplace where competition could be global from day one (Teece, 2007: 2010; Chesbrough, 2007). These aforementioned challenges embedded in the global business environment are arguably compounded for born global firms, as they often are small and new firms with limited resources and market presence, and acting in a context of uncertainty exploring new and nascent markets (Katila, et al., 2008; Santos and Eisenhardt, 2009). Thus, the ability to design business models for navigating this landscape of turbulence and uncertainty are crucial for born global firms and could be considered a distinguishing feature for this type of firms.

Until now, little is known specifically about how born global firms design their business model to act upon new opportunities in the international marketplace, and how they create and capture value over time in a global context. Due to both the lack of resources and the uncertainty of new markets, value is often cocreated with partners, suppliers and customers as well as competitors- with the challenge to generate value for the firm as well as for its stakeholders. The born global firm's performance is thus dependent upon boundary-spanning organizational arrangements which imply another set of challenges in itself. The business model is argued to be one of these boundaryspanning activities, and involves a simultaneous co-creation and capture of value in an ecosystem of partners (Zott and Amit, 2007; 2010). Moreover, in order to prosper and grow the firms need capabilities to adapt and transform its business model design over time, which is a complex art. More research is called for to provide insights into the process of business model innovation over time (Trimi and Berbegal-Mirabent, 2012). Business model innovation can be viewed as changes in how the firm does business in respect to how it creates, delivers and captures value (Amit and Zott, 2012; Teece, 2010; Teece, 2007). It can for instance be to redefine an existing product, service and value proposition and/or how the firm profit from the customer offering (Björkdahl 2009; Björkdahl and Holmen, 2013).

Despite the increasing academic attention to business models and born global firms, there is a dearth of research focused on why born global firms adopt a certain business model design, and how born global firms undergo processes of business model innovation to pursue rapid growth in multiple countries (with some exceptions see e.g. Dunford et al., 2010). Thus we ask the following research questions: How do born global firms use business models to act upon business opportunities? How does the born global firm manage business model innovation over time in order to grow in international markets? The purpose of this paper is to investigate how business model design is used by born global firms to act upon new business opportunities, and how they manage business model innovation over time to grow on international markets. To reach that purpose, we employ the dynamic capability perspective. Dynamic capabilities could be said to be based on the notion of the firm's need to build new competences, skills and reconfigure existing routines leveraging both internal and external resources (Teece 1997; 2007). In line with recent papers on dynamic capabilities (Helfat and Peteraf 2009; Schilke, 2013) we highlight a set of relevant business processes or challenges, which are 
derived from our empirical material. In the context of the born global firms in this study, these process and challenges relate to partner relationships, value chain positions, retention of entrepreneurial mindset of the firm and the foresight to navigate a dynamic business environment. Coing through these processes and dealing with the aforementioned challenges required a particular set of dynamic capabilities behalf of the case firms. We identified three distinct types of dynamic capabilities affecting business model design, innovation and international growth.

Empirically, we have conducted three exploratory case studies of born global firms that all have acted upon novel opportunities and created new market niches in their journey of internationalization. This article contributes both to the field of international entrepreneurship and born global research and to the emerging business model literature. Firstly, it provides longitudinal insights of born global firms past their early internationalization stage and provides insight to how they have sustained international operations and remained competitive for over a decade since inception, which is concurrent with research calls by Dimitratos (2005), Keupp et al. (2009) and Jones et al. (2011). Secondly, it enriches our understanding of how the use of business model designs and capabilities to manage business model innovation can contribute to firms' internationalization and growth. In order to advance the business model research we argue with other entrepreneurship scholars that focus must develop from what business models are towards what business models do (Doganova and Eyquem-Renault, 2009), and consequently how business models are used by the entrepreneurs. Finally, the paper identifies and articulates three interrelated type of dynamic capabilities to manage business model innovation in the context of born global firms: sensing capabilities, entrepreneurial capabilities and relational capabilities.

\section{Theoretical Background}

\section{Born Globals Acting in a Highly Competitive and Turbulent Context}

Starting in the early 90's, research noted that some young entrepreneurial firms followed a different pattern of internationalization, i.e. doing it rapidly after inception and often with a large scope. This contradicted past research of firms internationalization processes, which advocating slow, incremental patterns of internationalization. These young entrepreneurial firms have commonly been labeled either born global firms (Knight and Cavusgil, 1996) or international new ventures (Oviatt and McDougall, 1994) in the academic literature. They however tend to share a broad common definition, which we also follow in this study: "A business organization that, from inception, seeks to derive significant competitive advantage from the use of resources and the sale of output in multiple countries" (Oviatt and McDougall, 1994:50). Born global firms are often found in knowledge intensive and high tech industries with environmental turbulence (Oviatt and McDougall 1994; Autio et. al., 2000: Gabrielsson et al., 2004). However, these new and small firms often face dilemmas as characteristics which have facilitated the emergence of these firms, are also providing a set of challenges. These challenges could be in terms of internal and external pressures on the firm to innovate in a fast-phase and being internationally competitive, while these firms often are resource-scarce, niche-oriented, with limited market presence and international experience (Weeravardena et al., 2007; Sainio et al., 2011). This could provide for difficult tradeoff decisions as how to allocate a limited bulk of resources. (Autio et al., 2000; Gilbert et al., 2006). Arguably, this impacts business model design and business model innovation decisions for born global firms, as resource scarcity and other limitations might inhibit business model innovation.

\section{Business Model Design of Born Global Firms}

The academic interest in business models has increased during the past decade with extensive research focusing on what business models are in form of definitions and conceptualizations, although the construct is still being disperse and inconsistent in scope and focus (se eg. Teece, 
2010; Zott et al.,2011). Business models have been related to strategy (Teece, 2010; Chesbrough, 2010), entrepreneurship (Ceorge \&; Bock 2011; Huarng 2013) and international entrepreneurship (Sainio, et al., 2011). While our research aim is not to involve in the debate of definition of the concept, we contribute to the research field by revealing how business models and business model innovation are used in the context of born global firms, being a specific type of entrepreneurial venture. Business model design represents an important component in the opportunity recognition and exploitation of these firms (Downing, 2005; Franke et al., 2008; George \&; Bock, 2011). The identification, evaluation and exploitation of opportunities are also an emergent theme in the international entrepreneurship literature (Dimitratos and Jones, 2005; Sainio et al., 2011). The concept of business model being opportunity centric is therefore helpful in further understanding the behavior of born global firms. We follow the broad definition of business models by Teece (2010) as the design of how to identify, create and deliver value and how to capture parts of this value. Chesbrough et al. (2002) argues that a business model focuses more on value creation and value delivery rather than value capturing and competitive threats, where the latter concepts are more in the realm of strategy. However, as it is claimed by Teece (2010) that understanding how to capture value from innovation is a key element of business model design. These two logics of creating and capturing value are therefore intertwined and difficult to separate, in particular in situations of co-creation of value with other actors.

Zott and Amit (2010) defines business models as firms' activity systems consisting of certain dominant value creation drivers such as novelty, efficiency, complementarity and customer lockin. The efficiency-centered business model design relates to exploitation of business opportunities and the measures taken to achieve transaction efficiency through the business models. A business model designed for lock-in of either customers or partners can be manifested by high switching costs and network externalities derived from the business model design. A novelty- centered business model design relates to the exploration phase in the identification of new opportunities and new ways of doing businesses, which could include different constellation of partners, suppliers, customers and competitors. However the development of new opportunities is challenging for small firms, as is sustaining them over time (Bengtsson and Johansson 2012). An important capability is therefore how to balance the novelty and efficiency-based business models as well as managing the lockins, in order to sustain competitive over time. Over time and as the firm grow, these different value creation drivers and related structures often need to be managed simultaneously and tensions can emanate from their different logic of actions (March 1991). It requires a capability of the entrepreneur to manage a balance in particular between novelty and efficiency as they arguably are based on partially contradictory logics. Taken into consideration that born global firms are likely to face a limitation of resources this balance is even more important in order to prosper and grow on international markets.

\section{Business Model Innovation}

Business models and their designs are not static structures, but something which constantly needs to be reassessed and re-evaluated, as the hypotheses provided by the business model continuously are tested against a changing reality in the marketplace (Teece, 2010; Dunford et al., 2010). Hence, the need for business model innovation, which could be a pathway to a competitive advantage for firms as well as a form of corporate renewal. Similar to Amit and Zott (2012), we view business model innovation as changes in "how to do business". Specifically, we then consider changes in how firms create, deliver and capture value as business model innovations. Thus in concrete terms, this paper will operationalize business model innovation in accordance with Björkdahl and Holmén (2013) as "...to redefine an existing product or service, how it is delivered to customer and/or how the firm profit from the customer offering." In terms of firms operating in high-tech industries (as born global firms often are), it is often argued that 
technological innovation needs to be accompanied by business model innovation in order to capture value (Teece, 2010). In essence, a business model could both be a vehicle driving the innovation of the firms as well as being a subject of innovation by itself (Zott et al., 2011). However, as prior research indicates, once a business model has been set in an organization with activities and dedicated resources the structure can be difficult to change due to built-up routines with a risk of inertia and resistance to change (Zott and Amit, 2010). Business model innovation is though challenging and barriers for business model innovation could include a cognitive inability by managers to see the value of a new business model as well as resistance in form of established configurations of resources and processes within the firm, which could lead to a state of inertia. (Chesbrough, 2010) Taken together, the born global firms need certain capabilities to manage a balance between existing business models and business model innovation over time. Similarly, both a balance in acting upon novelty and efficiency in business model design, as well as capabilities to re-shape strategic choices according to different and changing market demands are needed (Trimi and BerbegalMirabent, 2012).

\section{Capabilities to Manage Business Model Innovation}

George and Bock (2011) call for further research into how business models and capability development of entrepreneurial firms may interplay. As born global firms are operating in a highly dynamic and competitive international business environment, with high demands of innovation, the firms arguably need to realign organizational practices, such as business models, to meet ever changing challenges, as discussed in the previous section. Thus, going by Teece's (2007) definition of dynamic capabilities: "...capabilities of sensing business opportunities, seizing them and managing threats/transforming the business", one can pinpoint a connection with change and innovation of the business model with the concept of dynamic capabilities. Thus, dynamic capabilities could then be viewed upon as capabilities of sensing business opportunities, seizing them and managing threats/ transforming the business (Teece 2007). However, a conceptual paper by Zahra et al. (2006) advocates the notion that dynamic capabilities are a higherorder capability, reshaping or reconfiguring lowerorder capabilities, called substantive capabilities. Substantive capabilities are fundamentally based on existing functional competences within the firm, whereas, consequently, dynamic capabilities could be utilized for changing or re-configuring those capabilities. (Zahra et al. 2006; Autio et al. 2011) Firms could though be more or less characterized by either substantive or dynamic capabilities at different circumstances or developmental stage and the interplay and balance between the two types of capabilities could be crucial for the firm's wealth creation (Zahra et al., 2006; Kreiser, 2011).

\section{Methodology}

This paper is built on three exploratory case studies of born global firms in the turbulent global industries of mobile communication, financial services and music distribution. A case study approach has been chosen as we study a context-dependent, complex and understudied phenomenon of how born global firm use business models to act upon opportunities (Eisenhardt and Graebner, 2007) This approach is most appropriate for understanding how and why firms act and react in managing business model innovations. The case study method allows both the description of network structures of the firms and their development processes over time.

The firms studied are Seamless Ltd., Xelerated Ltd and Toontrack Ltd. These three firms have all acted upon new opportunities, used their business models to create and capture value and managed to grow with the use of business model innovation. This is expressed by their growth in number of employees and turnover. All three case companies have during their journeys capitalized on new opportunities and internationalized in a fast phase. Descriptive data of the born global firms are provided in Table 1. 


\begin{tabular}{|c|c|c|c|}
\hline & Seamless Ltd. & Xelerated & Toontrack \\
\hline Founding year & 2001 & 2000 & 1999 \\
\hline $\begin{array}{l}\text { Number of em- } \\
\text { ployees (2012) }\end{array}$ & 120 & 91 (2011) & 24 \\
\hline $\begin{array}{l}\text { Turnover (year } \\
\text { 2012) }\end{array}$ & 20, 1 million USD & 14,6 million USD (2011) & 5,2 million USD \\
\hline $\begin{array}{l}\text { International } \\
\text { sales \% (2012) }\end{array}$ & $80 \%$ & $100 \%(2011)$ & $90 \%$ \\
\hline ISIC code & $\begin{array}{c}61200 \text { Wireless } \\
\text { Telecommunications } \\
62010 \text { Data Programing }\end{array}$ & $\begin{array}{l}72190 \text { Other science and } \\
\text { technological R\&D }\end{array}$ & $\begin{array}{c}59200 \text { Sound recording and } \\
\text { Music }\end{array}$ \\
\hline Key innovation & $\begin{array}{l}\text { Platform for pre-paid elec- } \\
\text { tronic distribution, mobile } \\
\text { payment ecosystem. }\end{array}$ & $\begin{array}{l}\text { Dataflow architecture for } \\
\text { high-speed programmable } \\
\text { network processing }\end{array}$ & $\begin{array}{l}\text { Audio library software for } \\
\text { professional and hobby mu- } \\
\text { sic production. }\end{array}$ \\
\hline
\end{tabular}

In order to increase the understanding of how business model innovation is managed over time we did undertake a longitudinal approach. We have followed the three case companies over a ten year period. The case study of Xelerated was conducted from year 2000 to 2012 (years 2000-2004 were studied retrospectively). The case study of Seamless was conducted from 2010 to 2013 (years 2001-2010 were studied retrospectively). Similarly the third case study of Toontrack was conducted from 2012 to 2013 and retrospectively from its start up. This approach with three case studies in different settings and studied over time can yield further accurate and robust theories compared to a single case study (Eisenhardt and Graebner, 2007). It also answers calls for longitudinal research on born globals firms and entrepreneurial firms in general (Jones and Coviello 2004; McKelvie and Davidsson 2009).
Business models can be depicted by "the stories that explain how the enterprise works" (Margetta 2002: 97). In order to understand how the entrepreneurs depict their business model and how it evolved, we listen to the entrepreneurs' stories of how different events and critical incidents emerged during their growth from identifying new opportunity, pursue of technological innovation and how they managed their expansion and growth with the use of business model innovations (Maitlis, 2005). These entrepreneurs offer their stories which link their personal aspiration and mindset to the operations, internationalization and growth of the firm, and the social context, therefore their stories offer a substantial ground to identify meaningful patterns (Dimov, 2010).

\section{Data collection}

The primary data for the study consist of ten interviews with entrepreneurs/CEOs and managers 
within the firms. The interviews were semistructured and the questions were thematically arranged. The interviews fell in the range of 90120 minutes each. The interviews were recorded and transcribed verbatim close after the interview. The initial interviews focused around the company background, perception of its development from the startup and growth on the international market, and structural questions about its ecosystems of customers, partners, suppliers and competitors and business model design. The following interviews became more structured and theme-based. See appendix 1 for the interview guide used. The respondents were asked to talk freely about their venture, how they sensed and acted upon opportunities in different situations, how and why its business model did change over time as the venture internationalize and grow, critical incidents in their journey and its effects, as well as processes and capabilities needed. The answers were followed up with questions such as "how," "why," and requests to "exemplify".

We have systematically analyzed archival data in form of company reports, industry reports, pressreleases and newspaper articles. The archival data was used as important complement to the stories of the entrepreneurs and as historical reference points to capture how and when the companies changed business model in order to capture new opportunities, new customers or entering new market niches.

\section{Data analysis}

We started the analytic work by analyzing each entrepreneur's narratives of their startups, how they acted upon opportunities, and how and why their business model have evolved and changed over time. From the narratives, complemented by archival data, the cases were written up in rather extensive detail to provide a general understanding of the context and chronology of the events. These early case descriptions were sent out to the respondents for approval and correction of any misinterpretations. The aim of this study is to develop theory and the analytic work has been an iterative process going back and forth, coding the empirical data (Maanen 1979; Nag et al. 2007), and comparing the findings to concept within the literature of born globals and more specifically opportunity identification, use of business models and firms' capabilities to manage business model innovation.

\section{Findings}

\section{Seamless}

Our first case is Seamless, a born global firm with a very insightful global journey where the firm continuously have used and transformed its business model to innovate, compete and grow on an international market. Seamless started as a spin-off in 1999 by an entrepreneur who identified a novel opportunity to rationalize the handling of all mobile pre-paid distributions by making it possible for users to recharge their pre-paid mobile account digitally. Seamless pioneered within this niche and with the use of its business model the entrepreneur created a new market. The journey of the firm show how it successfully have innovated, competed and grown on an international market and with several business model innovations over time.

The initial business model was designed as a joint venture with the world's largest card distributor, Brightpoint. Brightpoint had the market position, the customer base, the codes and Seamless had the technology to rationalize the pre-paid distribution. However, at this time the financial crisis came in early 2000 and the entrepreneurs realized that nothing was going to happen on a short-term basis. The entrepreneurs forced themselves to take a step back and reconsider how to proceed. Seamless decided at this stage to transform their business model and focus its activities becoming a software license company. With the corresponding business model Brightpoint became its customer and Seamless could reach the global market through the global customers' market channel. During this time Seamless technological innovation was launched globally in twenty countries and with Seamless product the entire market of pre-paid distribution was converted into electronic top up. 
"We developed a business model that was very successful and long-term it was remarkable nice. We were able to enter into an existing business and converge it into a digital business"

- Founder, VP Business Development Seamless

The value creation in this business model was built on a revenue share agreement, with no significant investments required from the customers, or the partners, which opened up for Seamless to enter into international markets through established distribution channels.

"if we look back it was successful, we travelled all around the world and signed contracts with a number of different companies that wanted to invest in this technology".

Seamless grew rapidly on the global markets, however, in 2001 the entrepreneurs found themselves trapped in the design elements of its business model, the company did not capture enough value although it grew rapidly in multiple countries. Their partners, sales agents and customers did not invest enough time and resources in order to develop into a viable and scalable business over time.

"here welearned the hard way the advantages and disadvantages to not have a business model that requires a firm to commit time and resources or capital investment", - Founder, VP Business Development Seamless

At this stage, the company transformed its business model once again in order to capture a higher level of value. During this time the company also brought in a new CEO with a background in the telecommunication industry. Seamless had operated indirectly with the telecommunication companies, but now it changed its focus and decided to sell directly to the large telecom system providers or to mobile operators. In 2005 Seamless started to collaborate with Ericsson in selected markets. The business model design at this phase was opposite from the first one. It focused on short-term revenues and mirrored Ericsson's business model of selling licenses. Another change with this business model was that Seamless took a step back in the value chain, from its position in direct relation with the distributors back to the OEM system solutions. In 2007, Seamless signed a global partnership agreement with Ericsson which enabled the born global firm to reach the leading mobile operators worldwide. This led to several important deals with mobile operators in Africa, Middle East and Asia and the born global firm grew on the international market together with the customer. With this business model Seamless technology eventually became an integrated part of Ericsson's prepaid charging portfolio. The set up with Ericsson helped Seamless to continue to grow on the international market and to learn about the business model design of "pay-as-you-grow" into different market. Seamless also directly signed a group frame agreement for the supply of its topup solution with MTN Group, the largest mobile network operator in Africa and Middle East.

Through the relationship with Ericsson and the mobile operators Seamless hence successfully entered and grew in the market. The integration of its platform into the system of these multinational partners gave value capture advantages such as long-term revenues and network externalities with a global reach as well as high switching costs. However, the disadvantage was that Seamless was a third party supplier, positioned far from the end-customer and more or less invisible as the system is sold as an Ericsson product, with a socalled white label model.

"We have continued to work with these two business models during the years, we have just refined and configured them towards different customers' demands", - Founder, VP Business Development Seamless

In a third phase during 2011-2012, Seamless once again innovated with a new business model, building on the established technological platform and distribution system of the company. Seamless 
got a new shareholder and CEO with background in the financial service segment and developed a new, third business model for the mobile money segment. At this stage, the organization found itself very colored by firstly the internet-based business model build on transaction and secondly the OEM model from telecommunication. However, Seamless now made a strategic move from selling products to become a service provider and released its solution SEQR for mobile payment. The value proposition to the customer, retail stores builds on cost-effectiveness and Seamless mobile money solution offer a decrease of 50 percent of the retailer's costs of transaction.

By business model innovation could Seamless entered into the mobile money market and were able to position it selves on the top of the value chain in direct interface with the end-customer.

"For the first time with SEQR we are taking the "elevator" up to the top of the value chain, we are no longer at the bottom floor, now we are in the penthouse", - Founder, VP Business Development Seamless

In 2013 Seamless had signed contracts with a number of international retail chains such as McDonalds as well as leading retail chains in Sweden (such as Axfood, Mekonomen and Nilson Group) and other segment such as Q-Park, one of the largest car parking operators. Seamless saw the potential with the existing customer base of millions of customers and billions of transactions from the digital distribution system and by innovating with the business model and position themselves on the top of the value chain. With this third business model innovation the company felt confident to not be a sub-supplier position under a bank or a telecom vendor as it includes the risk of being dependent as well as exchangeable during time when the technology matures and the competition is built on price.

With the business model invented for the mobile money segment the strategy is to expand the company and raise the volume of transaction and businesses; comparing its business model to Google's, building on scale and large volumes and to charge for added value services. However, although this business model holds a number of potential it is also comes with huge risks. Building an own brand towards end-customer are very costly, especially for a SME. However, it is a strategic choice made by Seamless and it's SEQR portfolio to not position itself further back in the value chain.

"Coincidently, we are in a way closer to the business model in stage one again, however, this time the revenues are higher and we are in control, which is a combination of financing and position in the value chain" - Founder, VP Business Development Seamless

The company currently uses all of the above mentioned business models as each business opportunities require a unique business model. The challenge with having multiple business models is however how to manage a balance and to combine the different business model designs.

"It's the challenge to balance these to gain revenue and invest in the new business model which is very expensive...it is gas and brake applied all the time"

The company also changed its internationalization strategies and decided to internationalize and grow through setting up own offices globally. In 2012 Seamless had offices in cities such as Accra, Calcutta, Lahore, Mumbai, Riga, Lodz and Sweden. In January 2013 it opened offices in England and Poland.

\section{Xelerated}

The second case is Xelerated, a born global firm that has gone through a process of pursuing technological innovation where both technological and market opportunities have been capitalized with the use of the firms boundary spanning business model. Xelerated is specialized on programmable network processors with a patent 
of a technology for programmable processing i.e. the dataflow architecture. Its business model has throughout journey focused on R\&D, design and sales as the production of the hardware is outsourced to a silicon foundry in Taiwan. Xelerated has deliberately changed the design elements in form of structure and content of the firm's eco system and network relationship of internationalization and growth.

Xelerated started in august 2000 as a spin-off by four experienced engineers. The founders had an innovative idea about how to control the data flow and invented architecture for programmable network processing of data at a very high speed. In the start-up phase the business model design was to develop the product, define and patent the dataflow architecture surrounding the application, search for external funding and recruit key staff. The network relations of the founders have always been the cornerstone in the company's action and vital part of the firm's creation of value. The founders had a list with names of people they wanted to recruit; former colleagues, people they knew to be competent engineers and trustworthy persons with extended personal networks in the industry. Xelerated went from eight to thirty employees in eight months during the start-up phase.

Already in the start-up phase Xelerated started to build an ecosystem of partners around its product. These partnerships are an important cornerstone in Xelerated's business model as its product is dependent upon interoperability with a number of partners. For example, in 2001 Xelerated initiated a partnership agreement with NetLogic, a partnership that have followed the born global firm through its journey to being recognized worldwide as a leading technology partner for high-speed network processing.

"Having a best-in-class network search engine supplier like NetLogic is critical to our success",

Founder, CEO Xelerated
In 2003 Xelerated received their network processor chip from its foundry, two and a half year after the company started and during this time the major market and sales phase began. The customers were multinational IT and telecom system vendors, such as Fuijitsu and Huawei. In this phase, Xelerated initiated cooperation with large partners to gain legitimacy in the sales activities with the global customers. Xelerated initiated a distribution agreement with Infineon a large supplier of semiconductor chips. Through this collaboration Xelerated accessed a global customer base.

"Our joint efforts have already paid off and by working with Infineon's worldwide sales force we will be able to go after an even larger customer"

Founder, CEO Xelerated

The business model arrangement between the two firms was that Infineon had production rights that could be used if Xelerated were unable to deliver its product. This arrangement reduced the customer's perceived risk of doing business with a small firm. Xelerated benefited from Infineon's credibility and resource strength as a large firm in their interactions with global customers, which was important for their development and growth.

Xelerated continued to build the ecosystem around its product as a part of the firm's boundaryspanning business model activities and made a number of joint sales trips with partners. In year 2002 Xelerated built strategic alliances with companies such as PMC Sierra, IDT and DUNE Network to secure interoperability and to do joint sales activities. The ecosystem of partners and interoperability between the parts was needed in order to deliver value to the global customers, which is illustrated with the following quotations.

"Demonstrating interoperability at highspeeds is a significant milestone that clearly shows Xelerated is on track and delivering on its promises",

Analyst The Linley Group 
"The partnership enables the development and deployment of system solutions that meet the rigorous demands for new generation",

VP Strategic Marketing

IDT.

"Our joint customers want to leverage their development investment across entire product families rather than point products",

Founder, CEO

Xelerated.

In 2006 the large Chinese equipment vendors Huawei and ZTE selects Xelerated product for its next generation network. China is an important growing market for Xelerated and gaining these leading firms as global customer made a clear footprint. In 2010, Huawei recognizes Xelerated as its best supplier, with IBM and Xilinx; shortly after, Xelerated was recognized as a core competence partner within a network of hundred companies. This strong recognition increased its legitimacy in negotiations with other large telecom providers.

Throughout the journey Xelerated have kept a business model where 60 percent is focused on R\&D activities with the strategy to sustain a front position and value proposition as being a best-of breed company. Companies with best-of-breed products have pioneered a segment and have developed most features of their products. The global customers want to include best-of-breed products into their solutions to deliver the most cutting edge technology to the market.

\subsection{Toontrack}

Toontrack, our third case company, started out in 1999 and was founded by a team of entrepreneurs with a passion for music and knowledge in writing computer software. The founders recognized an opportunity for simplifying music production for professionals and enthusiasts alike and in turn creating value for them by decreasing the time and costs involved by producing music.
"I believe that the timing was right for this when we first started out, as previously normal $P C^{\prime}$ 's would not yet be powerful enough for this type software to create much value",

- CEO

Toontrack

Toontrack's software permitted the user to use a pre-recorded audio library of drum sounds and insert those sounds into a music production by the user. This was a novel concept in the music industry at the time and soon the founder's found themselves getting email orders through the website from around the world to their office in one of the founder's apartment. The software was then just burnt on a CD and physically shipped by postal mail to the customer. Since then, the company has grown to 24 full-time employees and a turnover of almost 5.2 million USD the vast majority coming from international sales, by the end of the fiscal year 2012.

Over time, the business model of the firm has evolved as well, to facilitate this international growth of the firm. With the software and corresponding business model Toontrack developed a new market niche as illustrated by the following quotation;

"You can say that we started out just like a classical type of mail-order company. There was also no market for this before us, as we developed the product, we developed the market",

- CEO

Toontrack

Rather quickly, Toontrack decided to supplement the initial online sales business model, which existed from day one, with physical distribution to music stores. In 2002, Toontrack had already secured a contract with Sony and other international video game developers, for usage of the Toontrack audio library in video games. The following year, the company reached a distribution agreement with a large North American distributor, 
for a wider release of Toontrack's products in the United States through retailers in physical stores. As quoted in 2004:

"This is the world's most innovative and highly developed audio library and it will set a future international standard for this type

$$
\begin{aligned}
& \text { of software", } \\
& \text { - Co-founder and then CEO } \\
& \text { Toontrack }
\end{aligned}
$$

Even today, the sales revenues from the physical stores exceed those from the online sales.

"The gap (between the sales channels) is closing in and will probably continue to do so, but at the moment the majority of our sales comes from the physical stores",

- CEO

Toontrack

One of the advantages with selling through physical stores is that it decreases the costs of marketing for the young firm, which is still today only owned by its original founders and has never taken in any external ownership or capital. Toontrack soon learned the upsides of getting contracts with international distribution firms to get access to resellers abroad and thus tap into the international demand for their products, across both geographical as well as cultural boundaries.

"Obviously it is difficult for us here in Sweden to even know the five best stores to get into in say France or Japan, much less getting in touch with them. That is why the distribution contracts have been very beneficial for us in that regard. It could save us time, money and increases the scope of our market",

- CEO

Toontrack

Initially, this paid off quite well for Toontrack, by the end of 2005; the company had doubled its turnover for three consecutive years and had been profitable since its inception. However, having these distribution agreements also comes with a set of challenges, such as lack of control of the product for Toontrack and also the risk of losing the distributor if Toontrack's product does not meet certain sales targets and sometimes the distributor's willingness of marketing the product could decrease as well if they see a lack of interest from the re-seller side. Obviously, enlarging its value chain with distributors and resellers of course also cuts in the firm's value capturing ability in this business model. Recently, Toontrack cancelled the agreements with the distributors in Germany and the United States and exchanged it with a business model to deal directly with the stores for the purpose of gaining increased control of its products in those markets. Technological development, such as the increasing ease of downloading the software, is also contributing to the decreasing importance of distributors. As a function of that, the value delivery and value capturing aspects of Toontrack's business model will likely adapt to these changes in both technology and customer behavior.

\section{"It was not really possible to do the download type of business model before 2005, but today it is an established way of buying and delivering software. I think it will develop more as well, meaning that the customer will be more and more likely to buy directly from the producer." \\ - CEO \\ Toontrack}

Today, the niche market for music producing software has matured considerably and Toontrack could identify 3-4 main competitors to them on the international market and they are all using largely the same type of business models. Instead, the firms are mainly competing with price. Even though there are constant, albeit rather incremental, innovations in the product lines, such as Toontrack recently launching software set for piano sounds, leap-frogging away from the competitors is not easily accomplished.

"There is constantly a low-intensity war going on and everyone is watching what everyone is doing. If we release a new product today, 
everyone else will be doing the same or similar things tomorrow. Or vice versa."

Toontrack

However, the launch of the piano sound library in 2012, was however considered as a significant innovative step by the firm themselves and by their customers.

"Some of the customers think it is strange since our focus is drums. This is a completely different thing than we normally do; it is the same if Volvo would create bikes."

- CEO

Toontrack

At the same time, Toontrack still has to leverage and exploit its current product line and relationships, while actively trying to scan for input from a variety of stakeholders, such as partners and customers, to come up with both new and innovative products and well as potential business model innovations. In a rapidly changing business context such as computer software, Toontrack has evolved from burning CD's at an private apartment and posting physical goods to its customers, to a business model having customers directly download the software and receiving updates online from Toontrack, diminishing the importance of a vast network of international distributors, the decreases both control and sales margins for the focal firm. The latter business model also provides Toontrack with more avenues for direct contact with the customer and thus learning more about the customer's ideas, behavior and needs.

"We can see that we have room for making things easier for the customer in terms of purchasing and registering the products online. I also believe that customer contact is becoming more and more important, we want to be a firm that the customer could access easily to provide feedback and that really helps us as well.",

- CEO

Toontrack
"I guess that few people know what will happen to a company's business model in five years or whatever amount of time. The only certainty is change, one way or the other. Obviously we have to be ready for that, while still capitalizing what we are good at right now."

Toontrack

By the end of 2012, Toontrack was nominated for "Digital Gazelle Company of The Year" in Sweden, an awarded jointly given by Coogle and the Swedish business media. The aim of the award is to celebrate companies which are in the cutting edge of capturing online business opportunities creatively and efficiently. In the motivation for the nomination, the steps towards the newer business model of Toontrack were highlighted in the press release:

"Toontrack is a first-rate example of how the Internet is not merely a sales channel, but has the ability to act as an international storefront towards a global market".

\section{Discussion and Analysis}

\section{Design of Business Models to Act upon New Opportunities}

In line with previous research, our study demonstrates how the firms acted upon new opportunities to create and capture value with the use of business model designs, which in turn helped the firms to shape, and modify the business opportunity (Downing, 2005; Franke et al., 2008; George and Bock, 2011). Previous conceptual research proposes that entrepreneurial firms in early stages need to experiment with business model design to test the market and to act upon, or reject business opportunities (Trimi and Berbegal-Mirabent, 2012). The empirical insights in this article reveal how the three case companies differed in the ways they identified and created value of novel business opportunities in emerging markets niches. Seamless identified an 
opportunity to digitalize the prepaid distribution of mobile accounts. The initial business model design aimed at establishing a joint venture with a large distributor, Brightpoint, which resulted in an important customer relationship that enabled them to reach the global market with its invention. Xelerated invented a new data architecture and network processor and needed similar to Seamless to collaborate with large partners, or customers to exploit the market and internationalize. Xelerated further needed to build an ecosystem of complementary partners from its inception, in order to deliver value to the global customers. While Toontrack, in turn, could implement its online mail order business model to generate sales from day one, but at the later stage found itself in a situation where partnering with distributors and resellers were necessary for facilitating efficiency in terms of value delivery and further international growth. The three cases thus imply the importance of the designing a boundary spanning business model and to include partnering with large actors in the early internationalization of born global firms. Which is also in line with that business models in high-tech SMEs do not develop without significant cooperative relationships with other actors in the field (Nummela et al,. 2004). This leads us to the first proposition: Consequently, the following proposition is developed:

P1: Early-stage born global firms can utilize its partnering agreements with large actors to break out on international markets through a dynamic use of its business model design.

The initial value creation driver for all three companies was built on novelty in creating new technologies and value offerings (Zott and Amit, 2010). The novelty-based business models by the casecompanieswere to adifferentextent combined with elements of lock-ins of customers and/or complementary partners (Sainio et al., 2011; Oviatt and McDougall, 1994). We find that the partnering and the capability to build an ecosystem to cocreate value are deeply integrated and virtually inseparable from the business models as such. This finding partially contradicts that of Hennart (2013), who diminishes the importance of networks in favor of the business model as an explanation for born global firms' internationalization.

Moreover, in line with previous studies, the present study demonstrates that designing an opportunity centric business model requires intuition and a deep understanding of the key customer's needs (Teece, 2010). Through the close relationship with large, global customer, Xelerated and Seamless developed a deep understanding of the customers' needs and future roadmaps, which enhanced the SME's abilities to foresee future demands on international markets. Xelerated managed to develop elements of lock-in effects with both its large customers and ecosystem partners, due to the long product life cycles of the established systems, including both high switching costs of components and the customer advantages of network externalities (Zott and Amit, 2010). Seamless initial business model around its platform of prepaid distribution created similar customer lock in as once its platform is integrated into an OEM system, the switching costs are high as well as it generates advantages of network externalities. Toontrack, however, differs from Seamless and Xelerated in the sense that they target two different types of end-consumers, professional and "hobby" musicians. Thus it managed to create a lock in effect in their business model by the use of building legitimacy from users of the software, (Podolny 1994; Dacin et al., 2007). In form of well-known professional musicians, such as members in rock bands like Motley Crue, Megadeth, Def Leppard and Meshuggah. This leads us to the second propositions:

P2: $\quad$ Through lock in strategies together with a close understanding of customer needs, born global firms' can enter the larger customers international markets and capture value.

\section{Capabilities to Manage Business Model Innovation for Internationalization}

Our study further demonstrates how the born global firms developed and renewed their business models through processes of learning, experiencing 
and adopting to changes (Chesbrough, 2010; Doz and Kosonen, 2010). Specifically, we articulate three critical and interrelated capabilities facilitating business model innovation for born global firms to internationalize and grow in our analysis. These dynamic capabilities are sensing capability, entrepreneurial capability and relational capability, and are in line with Teece (2007; 2010), in regards to how dynamic capabilities could interplay with changes in the business model.

The capabilities are manifesting themselves in different forms and fashions, depending on the firm's internal dynamics, roles and positions in value chains, and the overall industry context at a given time. Seamless had new perspectives infused through their different market strategies and position in the value chain, while Xelerated drove towards enhancing its ecosystem and its own position by well-known, legitimacy building partners (Dacin et al., 2007). Toontrack in turn acted upon the opportunity when it recognized that the industry and customer acceptance had reached a point were direct downloading were commercially viable. The overarching commonality between these dynamic capabilities is however that they contribute to change where the capability to manage business model innovation drive these changes.

The journey of Seamless, from the firm's inception, demonstrate a sensing capability of capturing new opportunities to develop and build from its first technological innovation, the platform for prepaid distribution, to continuously sense and act upon new opportunities with a process of business model innovation. Seamless' journey show the capability to assemble resources for acting on and creating new business opportunities, which in accordance to Karra (2008) would make the firm's entrepreneurial capability high (see also Zang et al., 2009). However, in Seamless case the entrepreneurial capability created internal tensions as the company found itself being locked-in by the OEM business model with its large customers. In order to manage this situation Seamless uses relational capabilities in combination with continuous business model innovation to maneuver in its networks and enter new product markets and customers (Lee 2007; Andries and Debackere, 2007). In the case of Xelerated, the born global firms' business model has been continuously characterized by a strong focus on R\&D, design and sales activities and thus technology as well as market sensing for development purposes. Entrepreneurial capabilities and strong relational capabilities have also been evident in the firm's journey, as it enabled it to create a new market and to retain its position and best-of-breed status of its products over time. The cases of Seamless and Xelerated further show how lock-in strategies are two-sided in the relationship between large and small firms. The large customer use lock-in strategies to take control and incorporate the technology into its OEM solution (Bengtsson and Johansson, 2012). However, the small firm uses business model design to lock in the large customers as well. These action and reactions need to be managed through business model innovation over time in order for the small firm to sustain competitiveness and independence.

Toontrack have honed a strong sensing capability and actively scans competitors, customers and technological trends for the purpose of potential change and reconfiguration. The entrepreneurial capability of Toontrack manifested itself for instance in the launch of the piano audio library, thus acting on a new opportunity in the market, in line with Karra's (2008) notion of entrepreneurial capability. As for relational capability, Toontrack have been able to leverage resources from a dynamic usage of partners such as distributors and resellers for international growth and increasing the firm's own knowledge base, thus spurring further innovation in the firm.

P3: Born global firms idiosyncratically utilize its sensing, entrepreneurial and relational capabilities to manage business model innovation over time.

Moreover, as presented by Zahra et al. (2006) and Kreiser (2011), we also found that these firms possesses substantive capabilities as 
well and that they at different points in time of the firm's development and growth, could be more characterized by influences of substantive rather than dynamic capabilities. This could delay business model innovation or slowing down the process. Which could be exemplified in our cases by firms being locked-in into a OEM business model or a position in a value chain through their partnerships, generating substantive "being good at what you do" type of capabilities. It is mostly evident in the cases of Seamless and Xelerated. For Toontrack, the issue could be seen in a reluctance of venturing into new products, when they were already established with the drum audio software and arguably reaching a "comfort zone", honing the development of substantive capabilities in the firm. The same could be said about the firm's rather slow process towards direct downloading of the software as the model for purchase. The often young and resource-scarce born global firms are depending on its ability to make the correct tradeoff decisions in a highly competitive international marketplace. Hence, we argue that the balancing capability of the firm's management could balance the dynamic and the substantive capabilities of the firm and thus moderating the speed and scope of business model innovation. This leads us to the following proposition:

P4: Born global firms need to utilize a balancing capability for managing explorative and exploitive elements of business model innovation

This notion is highlighted in the cases, where for instance Seamless through its continuous business model innovation and changes in its management structure allowed the balance between the capabilities to be favorable changed for the firm at different points in time. For Toontrack, its strong sensing capability have played a large role for the management towards balancing tendencies towards complacency with the instilling the need to respond to market and technological shifts with changes in the business model. Similar could be noted for Xelerated, as through its intensive R\&D efforts and sensing capability, have pushed the firm's management to effectively balance the overall dynamic and substantive capabilities to avoid lock-ins and business model inertia (Chesbrough 2010; Zott and Amit 2010). Conversely, the balancing capability could also come into play for making sure that the business model innovation does not go too fast for the market. Case in point could for instance be Toontrack's slow shift towards direct downloads, where the business model innovation is balanced and moderated by the management, in order for the market to adjust to the technological shift incrementally.

\section{Conclusions}

This paper contributes to both the literature of born globals and business models in different ways. First, several calls for further research in the area of international entrepreneurship and born global firms have asked for studies of firms beyond early internationalization and firms of a very young age (Dimitratos, 2005; Keupp 2009; Jones et al. 2011). Secondly, how these firms can sustain their international operations and remain competitive over time, have been another recurring theme in research calls (Keupp, 2009). Thirdly, the concept of business models has not been used in born global research to a large extent previously (Dunford et al. 2010). Therefore, this study contributes to the literature of born global firms by looking at born global firms which are all more than 10 years of age and who has managed to sustain their competitiveness internationally since their inception. Specifically, we shed lights upon how the business models and the capabilities to manage business model innovation have contributed to the growth and development of these born global firms. Fourth, we identify and articulate three critical and interrelated capabilities used in the processes of business model innovation for the studied born global firms, namely opportunity sensing capability, entrepreneurial capability and relational capability. These inter-related capabilities are important for the firms to identify new opportunities and manage business model innovation over time in order to prosper and grow. This paper extend prior research of SMEs alliance 
portfolio management capabilities (Bengtsson and Johansson 2012) with the specific focus on born global firms business model design and capability to manage business model innovation over time, explicitly using these three capabilities to sensing novel opportunities, leverage network relationships to enhance its visibility and climb the ladders of their value chains.

Moreover, born global firms could then be argued to have a need for balancing the dynamic and the substantive elements of their capability portfolio for facilitating optimized value capturing from their business model innovation efforts. This as novelty-based business models, business model innovation and dynamic capabilities (Zott and Amit 2010; Teece 2007; 2010) for spurring the former, could be considered explorative efforts. Similarly, efficiency-based business models and substantive capabilities could be seen as exploitative measures in this context. Thus, this study highlights how these born global firms needs are utilizing a balancing capability from their management for effectively balancing the elements of exploration and exploitation in regards to business model innovation. This line of thought in regards to the exploration-exploitation duality is line with Nielsen and Gudergan (2012), as we thus argue that exploration and exploitation in this context represents different objectives and intentions, resulting in different outcomes for the firm. This differs from the continuum view of exploration and exploitation (i.e. March, 1991). As the cases have highlighted, business model innovation could be more incremental or radical depending on the context and the situation facing the firm at a particular point in time.

Finally, prior conceptually based research states that "the process of defining, adjusting and improving a business model is a complex art that needs further research efforts" (Trimi and BerbegalMirabent 2012: 455). This study complement previous studies of born global firms as well as the growing research on business model innovation by providing insights of the journey of three born global spanning over a ten year period, how these firms design business models to act upon business opportunities and the capabilities to manage business model innovation over time in order to internationalize and grow.

\section{Future Research}

This paper provides several interesting potential avenues for further research in the area of how business models are used. For instance, in our cases we noted that firms often used multiple different business models in parallel to each other. This is an issue not explicitly looked at in past research and we believe more knowledge is needed in order to understand how multiple business models are balanced by often resource-constrained SMEs, as well as drivers for opting to work with parallel business models. This could be viewed upon in the context of born global firms as well as in other types of firms; arguably this avenue of research is best suited for qualitative case studies. Another interesting venue for further research is to further scrutinize the lock in and lock out strategies as act of balancing the asymmetric relationship of small and large firms and its effects.

We also see a need to further explore the role of networks in the business model of born global firms. Hennart (2013) for instance, treat networks and collaborations separately from business models, while arguing that latter are a more significant driver for the development of born global firms. In our paper, we see a rather distinct connection between the use of networks, business models and dynamic capabilities in the context of born global firms. This could be further investigated quantitatively, through survey data, as well as through case studies. For instance, by looking at the dynamic capabilities involved and potential business model implications of network re-configurations by born global firms.

Additionally, the set of propositions provided here could use further empirical testing, either as a part of a survey or through qualitative work in different industry or geographical settings.

\section{Managerial Implications}

This study provides a set of practical implications for managers in growing and maturing born global firms. 
These implications are not limited to born global firms and can, to some extent, be transferable to other, similar types of firms as well. Firstly, we see that without a carefully designed business model, relevant for the current stage the firm is in, technological innovations will fail to capture a market. Thus, the business model is at least as important for the success of ventures as the technical innovativeness. Secondly, as the firm evolves, so should the business model. The business model which allowed the firm to enter global markets in first place will likely not be the business model for sustained growth as the firm matures. This is due to ever-increasing global competition, technological advancements and changes in customer behavior, for instance. Thirdly, as the cases in this study have highlighted, business model innovation is a process which require certain capabilities and needs to be managed carefully. At one hand, the firm needs to sustain competitiveness and avoid inertia, even at a rather young age, but at the same time not moving too fast and alienate customers. Finally, the firm's external networks and partnerships should be treated dynamically and hence be adjusted and/or re-configured/as the firm's business model changes overtime.

\section{References}

Amit, R. \& Zott, C. (2012). Strategy in changing markets: New Business models - Creating value through business model innovation. MIT Sloan Management Reviews, 53, pp. 41-49.

Andries P. \& Debackere K. (2007) Adaptation and Performance in New Businesses: Understanding the Moderating Effects of Independence and Industry, Small Business Economics, 29(1-2), pp. 81-99

Autio, E., George, G. \& Alexy, O. (2011.) International Entrepreneurship and Capability Development-Qualitative Evidence and Future Research Directions. Entrepreneurship: Theory \&; Practice, 35, pp.11-37.

Bengtsson, M. \& Johansson, M. (2012). Managing coopetition to create opportunities for small firms. International Small Business Journal, (December). Available at: http://isb.sagepub.com/cgi/doi/10.1177/0266242612461288 [Accessed January 11, 2013].

Björkdahl J. \& Holmén M. (2013) Editorial: Business model innovation - the challenges ahead. Int. J. Product Development, Vol. 18, No 3-4. pp. 213-255.

Chesbrough, H. \& Rosenbloom, R.S. (2002). The Role of the Business Model in Capturing Value from Innovation: Evidence from Xerox Corporation's Technology Spinoff Companies. Business, 11(3), pp.529-555.

Chesbrough, H. (2006) Open business models: How to thrive in the new innovation landscape. Harvard Business School Press. Casadesus-Masanell, R. \& Ricart J.E. (2010) From strategy to business models and onto tactics. Long Range Planning 43.(2) pp. 195-215.

Coviello, N. E., \& Jones, M. V. (2004). Methodological issues in international entrepreneurship research. Journal of Business Venturing, 19(4), pp. 485-508.

Coviello, N.E. (2006) The network dynamics of international new ventures. Journal of International Business Studies 37(5) pp. 713-731.

Dacin T.M., Oliver C. \& Roy J-P. (2007) The legitimacy of strategic alliances: An institutional perspective. Strategic Management Journal 28(2), pp.169-187.

De Clercq, D. \& Voronov, M. (2009) Toward a Practice Perspective of Entrepreneurship: Entrepreneurial Legitimacy as Habitus. International Small Business Journal, 27(4), pp.395-419. 
Downing, S. (2005) The social construction of entrepreneurship: Narrative and dramatic processes in the coproduction of organizations and identities.Entrepreneurship Theory and Practice 29.2 (2005) pp. 185-204.

Dimov, D. (2010) Nascent Entrepreneurs and Venture Emergence: Opportunity Confidence, Human Capital, and Early Planning. Journal of Management Studies, 47(6), pp.1123-1153.

Dimitratos, P. \& Jones M.V. (2008) Future directions for international entrepreneurship research.International Business Review 14.2, pp. 119-128.

Doganova, L. \& Eyquem-Renault, M. (2009). What do business models do? Research Policy, 38(10), pp.1559-1570.

Dunford R. \& Palmer I., Benveniste (2010) Business model replication for early and rapid internationalization, the ING direct experience, Long Range Planning 43(5-6) pp. 655-674.

Fernhaber, S.A., McDougall, P.P. \& Oviatt, B.M., 2007. Exploring the Role of Industry Structure in New Venture Internationalization. Entrepreneurship: Theory and Practice, 31(4), pp.517-542.

Franke, N., Gruber M., Harhoff D., Henkel J. (2008) Venture Capitalists; Evaluations of start-up teams trade-offs, knock-out criteria, and the impact of VC experience. Entrepreneurship Theory and Practice 32, 3, pp. 459-483.

Gabrielsson, M. et al. (2008). Born globals: Propositions to help advance the theory. International Business Review, 17, pp.385-401

George, G. \& Bock, A.J., (2011). The Business Model in Practice and its Implications for Entrepreneurship Research. Entrepreneurship: Theory and Practice, 35(1), pp.83-111.

Gilbert, B.A., McDougall, P.P. \& Audretsch, D.B., (2006). New venture growth: A review and extension. Journal of Management, 32(6), pp.926-950.

Helfat, C.E. \& Peteraf, M. a., 2009. Understanding dynamic capabilities: progress along a developmental path. Strategic Organization, 7(1), pp.91-102.

Hennart, J. (2013). Internationalists: A theory of Born Globals. Entrepreneurship Theory and Practice.in press: doi:10.1111/etap.12076

Huarng, K-H. (2013) A two-tier business model and its realization for entrepreneurship. Journal of Business Researchm in press. Jones, Marian V, Nicole Coviello, and Yee Kwan Tang (2011). International entrepreneurship research (1989-2009): a domain ontology and thematic analysis. Journal of Business Venturing 26.6 pp. 632-659.

Keupp, M.M. \& Gassmann O. (2009) The past and the future of international entrepreneurship: a review and suggestions for developing the field.. Journal of Management 35(3)

Knight, Gary A, \& Tamer Cavusgil S. (2005). A taxonomy of born-global firms. MIR: Management International Review (2005), pp. 15-35.

Kreiser, P.M. (2011) Entrepreneurial orientation and organizational learning: The impact of network range and network closure. Entrepreneurship Theory and Practice 35.5 pp. 1025-1050.

Lee G.K. (2007). The significance of network resources in the race to enter emerging product markets: The convergence of telephony communications and computer networking 1989-2001. Strategic Management Journal, 28 pp. 17-37

Nielsen, B. B., \& Gudergan, S. (2012). Exploration and exploitation fit and performance in international strategicalliances. International Business Review, 21(4), 558-574. 
Maanen, J. Van, (1979). The fact of fiction in organizational ethnography. Administrative Science Quarterly, 24(December). March J. (1991) Exploration and exploitation in organizational learning, Organizational Science 2, pp. 71-87.

Magretta, J. (2002) Why business models matter. Harvard Business Review, 80(5) pp. 86-92.

Maitlis, S. (2005). The social process of organizational sensemaking, University of British Columbia. , 48(1), pp.21-49.

McDougall, P.P., Shane, S. \& Oviatt, B.M. (1994) Explaining the formation of international new ventures. The limits of theories from international-business-research. Journal of Business Venturing, 9, pp.469-487

McKelvie, A., \& Davidsson, P. (2009). From resource base to dynamic capabilities: an investigation of new firms. British Journal of Management, 20(1), pp. 63-580.

Moen, O. \&; Servais, P. (2002) Born global or gradual global? Examining the export behavior of small and mediumsized enterprises. Journal of International Marketing, 10, pp.49-72.

Oviatt, B.M. \& McDougall, P.P. (1994). Toward a theory of international new ventures. Journal of International Business Studies, 25, pp.29-41.

Podolny JM (1994). Market uncertainty and the social character of economic exchange. Administrative Science Quarterly 39(3) pp. 458-483.

Prange, C. \&; Verdier, S. (2011). Dynamic capabilities, internationalization processes and performance. Journal of World Business, 46(1), pp.126-133.

Saino L.M., Saarenketo S., Nummela N., Eriksson T. (2011) Value creation of an internationalizing entrepreneurial firm, the business model perspective, Journal of Small Business and Enterprise Development, 18(3) pp. 556-570.

Santos, F.M. \&; Eisenhardt, K.M.. (2009). Constructing Markets and Shaping Boundaries: Entrepreneurial Power in Nascent Fields. Academy of Management Journal, 52(4), pp.643-671.

Schilke, 0., 2013. On the contingent value of dynamic capabilities for competitive advantage: The nonlinear moderating effect of environmental dynamism. Strategic Management Journal, 203(January 2012), pp.179-203.

Strauss A and Corbin J (1990) Basics of qualitative research. Newbury Park CA: Sage.

Teece, D.J. (2010) Business Models, Business Strategy and Innovation. Long Range Planning, 43(2-3), pp.172-194.

Teece, D.J. (2007). Explacing dynamic capabilities: The nature and microfoundations of (sustainable) enterprise performance, Strategic Management Journal, 1350(August), pp.1319-1350.

Trimi, S., \& Berbegal-Mirabent, J. (2012). Business model innovation in entrepreneurship. International Entrepreneurship and Management Journal, 8(4), 449-465.

Zahra, S.A., Sapienza, H.J. \& Davidsson, P.(2006) Entrepreneurship and Dynamic Capabilities: A Review, Model and Research Agenda. Journal of Management Studies, 43(4), pp.917-955.

Zott, C. \& Amit, R, (2007). Business Model Design and the Performance of Entrepreneurial Firms. Organization Science, 18(2), pp.181-199.

Zott, Christoph \&; Amit, Raphael, (2010) Business Model Design: An Activity System Perspective. Long Range Planning, 43(2-3), pp.216-226.

Weerawardena, J.. Mort G.s., Liesch P.W., Knight G. (2007). Conceptualizing accelerated internationalization in the born global firm: A dynamic capabilities perspective. Journal of World Business, 42, pp.294-306 


\section{Appendix 1: Interview Guide}

\section{Background:}

- Can you briefly describe your business today?

\section{OVERALL ON THE NETWORK, THE PRESENT SITUATION:}

- Customers

- Suppliers

- Partners

- Competitors

\section{Business models}

- How does your business model look like? (If possible, draw it)

- Why have you chosen / developed this model?

- Has it changed over time, if so how and why?

- What are the driving forces have been behind the change of the business model, what effects have it had?

\section{Business models cases}

- Can you describe two different internationalization cases that you have done recently with a client or with partners?

- The process, from product/service introduction to customer contracts (or vice versa).

- Can you describe one or more critical incidents that had an impact on how the project / business evolved?

\section{Business models and international growth}

- Do you believe that the business model and the innovations made to the business model overtime (if any) has contributed to the growth of the firm, and in that case, how and why?

- Do you believe that your current business model is replicable across the international markets you are current active on and consider to be active on? If so/not, why?

- What challenges do you see for the future with the business model you have today and your international growth?

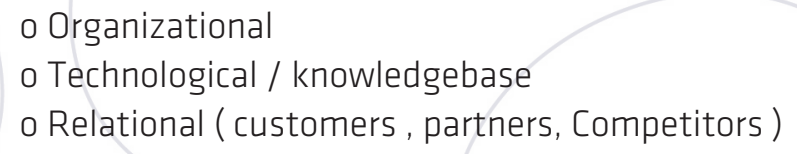

- What opportunities do you see your business model and your international growth?

a Technological / knowledgebase

b. Related Market

c. Strategic 


\section{Business models and Capabilities}

- What do you see in terms of skills / abilities in the company?

- How does your network and even competitors affect the learning the building of competences/skills/capabilities within the company and it has affected the business model?

- Do you work actively to create market changes on your own/ create new markets? How, if so? How can it affect the business model?

- Are there any mental barriers in the organization that makes it difficult to change the business model?

T) For example, we are so used to doing this it's hard to see it any other way

- How can you characterize your company's willingness to act upon changes; Do you act or react upon changes in the environment?

\section{Summering up}

Do you think that your business model(s) are the same in three, five or ten years? How, why, can you give examples.

- Is there anything else you would like to add that we have not discussed related to the business models and internationalization? 


\section{About the authors}

Dr Marlene Johansson is an Assistant Professor of entrepreneurship and innovation at the Entrepreneurship section, Umeå School of Business and Economics. Marlenes current research interest focus on business model innovation, entreprenurship, coopetition and strategic alliances. She has published in journals such as International Small Business Journal, the IMP Journal, and European Business Review. Apart from research she is currently Studio Director for Sliperiet, a unit for collaboration, creativity and innovation at Umeå University.

Jan Abrahamsson is Ph.D Candidate at Umeå School of Business and Economics, within the unit of Entrepreneurship and Innovation. Jan's position is partially financed through the CiiR (Centre for Inter-organizational Innovation Research) project, a Swedish national excellence centre within business research. His research focuses on internationalization, development and business models of entrepreneurial firms. He furthermore has a BSC degree from Luleå University of Technology in business administration, focusing on both management accounting and industrial marketing as well as a MSc from Umeå School of Business and Economics, focused on business development and internationalization. He also have previous professional working experience from entrepreneurial firms within the ICT sector.
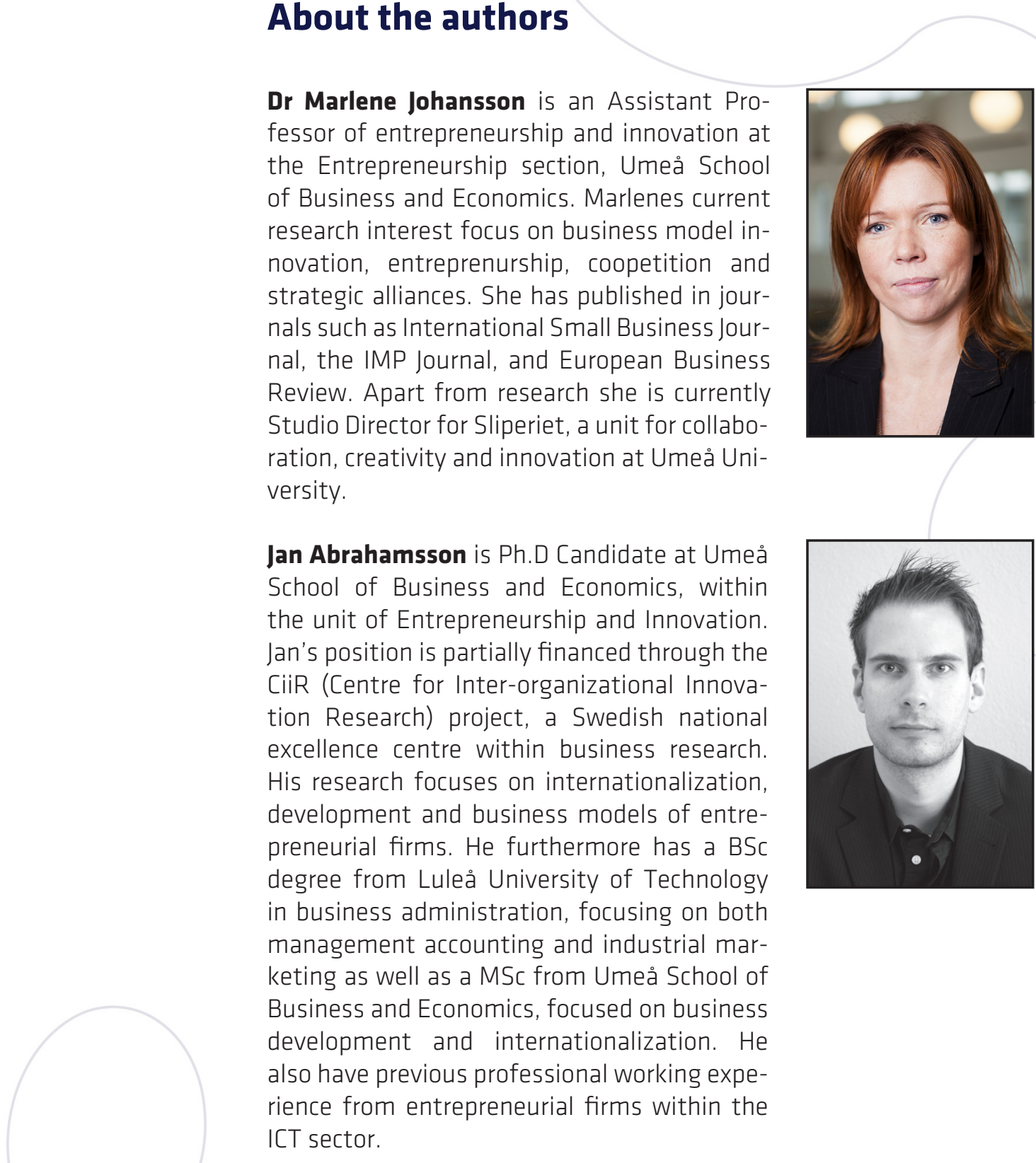